\title{
Self and Peer Assessment at Problem-Based Learning (PBL) Sessions at the Faculty of Medicine, King Abdulaziz University (FOM-KAU), KSA: Students Perception
}

\author{
Hani S Atwa ${ }^{1,2^{*}}$ and Al Rabia MW ${ }^{3}$ \\ ${ }^{1}$ Ibn Sina National College for Medical Studies, Jeddah, Saudi Arabia \\ ${ }^{2}$ Suez Canal University, Egypt \\ ${ }^{3}$ Faculty of Medicine, King Abdulaziz University, Jeddah, Saudi Arabia
}

*Corresponding author: Hani S Atwa, Ibn Sina National College for Medical Studies, Jeddah, Saudi Arabia, Tel: 201224576171/966593763061; E-mail: doctorhani2000@yahoo.com

Rec date: April 22, 2014; Acc date: May 15, 2014; Pub date: May 23, 2014

Copyright: (C) 2014 Atwa HS, et al. This is an open-access article distributed under the terms of the Creative Commons Attribution License, which permits unrestricted use, distribution, and reproduction in any medium, provided the original author and source are credited.

\begin{abstract}
Introduction: In 2007, the Faculty of Medicine, King Abdulaziz University (FOM-KAU) has introduced PBL into its integrated, systems-based curriculum to encourage the development of important skills. Among such skills are problem-solving skills, verbal and written communication skills, leadership skills, teamwork skills, and self- and peerassessment skills.

Purpose: The purpose of this research work was to investigate whether self- and peer-assessment are done or neglected in PBL sessions at FOM-KAU, and how students perceive them in terms of their benefit.

Material and Methods: This is a descriptive study that has been performed at the FOM-KAU on a random sample of students in Year $3(n=60)$. A self-administered questionnaire (survey) was developed and administered to the students at the end of the debriefing session of a PBL case to investigate their perception of self- and peerassessment and whether they are done or not. Descriptive statistics were used, as frequency distribution and comparisons.
\end{abstract}

Results: Nearly all of the students in our sample positively perceive the importance and merits of self- and peer assessment. Also, most of the students (83\%) said they do self-assessment after PBL sessions, while only $55 \%$ of them said they do peer-assessment after PBL sessions.

Conclusion: Self- and peer-assessment are done in FOM-KAU with different percentages, where selfassessment is done more frequently. Based on their importance, they are positively perceived by the majority of the students in our sample, which provides a good ground for implementing and monitoring a sound strategy for selfand peer-assessment based on pre-determined criteria.

Keywords: Self-assessment; Peer-assessment; PBL; Curriculum

\section{Introduction}

In 2007, The Faculty of Medicine, King Abdulaziz University (FOM-KAU) was among the first medical schools in Saudi Arabia to reform its undergraduate curriculum to an integrated curriculum that incorporates the organ-system modules and a hybrid PBL program. This kind of reform aimed at replacing the old curriculum (a traditional one) that was taught as separate courses by individual departments [1].

PBL is a modern learning strategy that first originated in the 1950s at the medical school at Case Western Reserve University. Then, in the 1960s, McMaster University in Canada introduced it. It was initially introduced as a method of educating physicians to apply their knowledge in the context of real patient health problems $[2,3]$.

The rapidly expanding knowledge base in different subjects necessitated the presence of a way for dealing with the tremendous amount of knowledge. So, implementation of PBL effectively shifted emphasis away from just collecting and assimilating amounts of knowledge to enabling the students to learn effectively and independently. In this way, PBL was viewed as a way to align learning at the classroom with professional practices outside the medical school [3].

"PBL is a method of learning in which students first encounter a problem, followed by a student-centered inquiry process"[4-6]. In the PBL process, learning is initiated by and structured around complex problems rooted in situations that the learner is likely to encounter in the real world outside of school [7].

PBL is believed to motivate, teach clinical reasoning; store relevant information in an integrated way, and in the way it will be retrieved and applied; tie learned information to a vivid experience, thus helping long term memory, facilitating recall and the transfer of that information to future related problems; reduce the overload of nonrelevant factual material; and promote self- and peer-assessment and life-long self-learning skills. All these are accomplished in an active, 
interactive and satisfying way [8]. So, self- and peer-assessment skills are among the skills encouraged by PBL, although the PBL curriculum does not guarantee the appropriate development of such skills [9].

Self-assessment is judging the quality of one's own work. It helps students to develop an understanding and judgment of the quality of their own work. Uncovering a gap in knowledge or in clinical performance motivates self-directed learners to try to close it. A gap discovered through self-assessment is more salient than one exposed by someone else [10]. Reflection and self-assessment are essential components of skill-building [9]. Factors affecting the level of selfassessment skills may encompass interaction of individual personality traits and pre-school education [11].

Peer-assessment is the act of peers assessing one another [12]. Although there is a debate regarding the workability of peerassessment in PBL [13], its great value in helping students developing an understanding and judgment of the quality of peers' work is unquestionable.

In order to make self- and peer-assessment a success and allow the students to get the most of their benefits, students must understand of the criteria that they assess performance against in order to be able to assess self and peers $[14,15]$.

Self- and peer-assessment have many potential advantages in common and are often combined or considered together. Peerassessment can help self-assessment, as when someone judges the work of others he gains insight into his own performance. "Peer and self-assessment help students develop the ability to make judgments, a necessary skill for study and professional life" [16].

Brown et al. [16-18] and others have described some advantages as:

- Giving the student a sense of ownership of the student assessment process, which improves student motivation to learn

- Encouraging students to be responsible for their own learning, hence developing them as self-learners

- Treating assessment as part of the learning process, where mistakes are opportunities rather than failures

- Practicing the transferable skills needed for life-long learning, especially evaluation skills

- Using external evaluation to provide a model for internal selfassessment of a student's own learning (metacognition), and

- Encouraging deep rather than surface learning.

Self-and peer-assessment helps students evaluate their own and their peers' work, which is a skills needed for promoting lifelong learning.

However, Machado et al. [19] concluded that peer- and selfassessment marks might be reliable but not valid for PBL tutorial process, especially if these assessments are used for summative assessment.

Using self- and peer-assessment is more common in formative assessment, perhaps due to concerns about the validity and reliability of students having responsibility for awarding summative grades to their peers. However, they are still used frequently in summative assessment. Even when not used directly in summative assessment, self- and peer-assessment can inform summative marking, especially with regard to assessing group work where it can be helpful in gauging individual contributions to a group task [20].
Falchikov et al. [21] documented the stages to be followed when carrying out and evaluating self- and peer-assessment. Teachers have a great role in all of these stages, especially in the preparation and follow-up. These stages include:

- Preparation, where identifying criteria for assessment, raising the awareness of students and supplying them with the rationale behind the whole process, and preparing the checklists are carried out;

- Implementation, where checklists and criteria are used by the students to mark their own/peer performance, then feedback and justification is given by students to peers;

- Follow-up and evaluation, where feedback about the process is collected and analyzed to identify problems and work on them; and finally

- Replication, where the process is replicated with same and similar students.

Self- and peer-assessment can be used as effective tools for developing the field work skills. However, it is not a simple task to assess one's work. Rating errors in assessment can emerge, especially because students are often novices in assessing the work of a peer [22].

There are several issues that can stand against performing self- and peer-assessment by the students. Among these issues is the reluctance of the students to judge a peer or allow a peer to judge him/her, to avoid any conflicts or hard feelings between colleagues.

The purpose of this work is to investigate whether self- and peerassessment are done or neglected in PBL sessions at FOM-KAU, and how students perceive them in terms of their benefit.

\section{Material and Methods}

This study is a descriptive one that has been performed at the FOMKAU. A random sample of students in Year $3(n=60)$ were included in the study. Year 3 was chosen because the PBL curriculum is applied mainly in that school year.

Survey forms were administered to the students at the end of the debriefing session of a PBL case. Clarification of students' inquiries and concerns were done by the researcher.

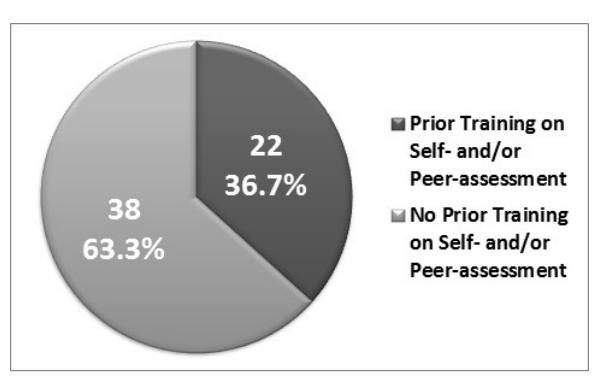

Figure 1: Prior exposure to training on self- and/or peer-assessment

Collected data were coded and entered into a computer and processed using the IBM SPSS v. 20. Descriptive statistics were used, as frequency distribution and comparisons. The level of $\mathrm{p}<0.05$ was considered as the cut-off value for statistical significance.

Figure 1 shows that about one third of the students were exposed to training on self- and/or peer-assessment before practicing it at the PBL 
Citation: Atwa HS, Al Rabia MW (2014) Self and Peer Assessment at Problem-Based Learning (PBL) Sessions at the Faculty of Medicine, King

Page 3 of 6

sessions. Training here means any formal (curricular) or informal (extra-curricular) training.

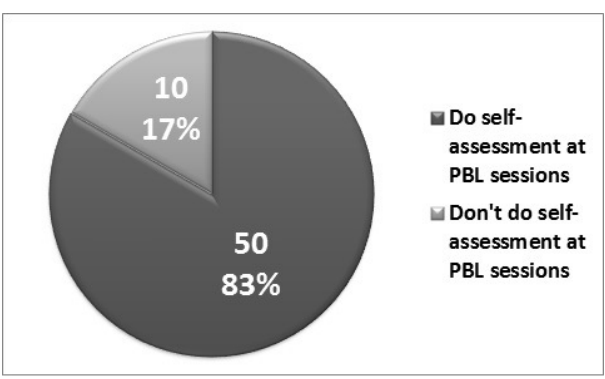

Figure 2: Doing self-assessment at PBL sessions or not

Figure 2 show that the majority of the students do self-assessment at the PBL sessions.

\begin{tabular}{|l|l|l|}
\hline Area of Self-assessment & Number (N) & Percentage (\%) \\
\hline Overall performance & 48 & $96 \%$ \\
\hline Attitude toward peers & 44 & $88 \%$ \\
\hline Attitude toward tutor & 43 & $86 \%$ \\
\hline Degree of contribution in discussions & 46 & $92 \%$ \\
\hline Clarity of presented information & 42 & $84 \%$ \\
\hline Helpfulness to other group members & 37 & $74 \%$ \\
\hline Weaknesses as well as strengths & 46 & $92 \%$ \\
\hline
\end{tabular}

Table 1: Areas of self-assessment at PBL sessions $(n=50)$.

Table 1 show that the great majority stresses on all areas of selfassessment, especially their own overall performance in PBL sessions.

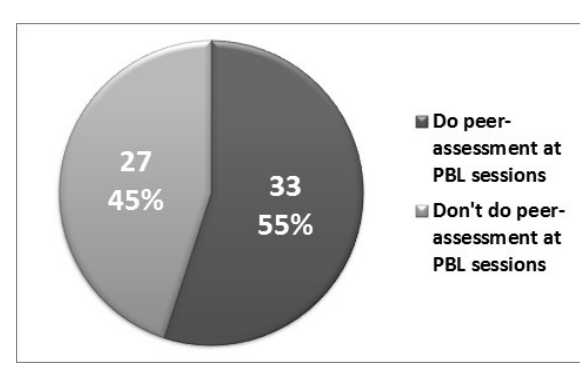

Figure 3: Doing peer-assessment at PBL sessions or not

Figure 3 show that nearly half of the students do peer-assessment at the PBL sessions.

\begin{tabular}{|l|l|l|}
\hline Area of Self-assessment & Number (N) & Percentage (\%) \\
\hline Overall performance & 31 & $93.9 \%$ \\
\hline Attitude toward peers & 25 & $75.8 \%$ \\
\hline Attitude toward tutor & 24 & $72.7 \%$ \\
\hline
\end{tabular}

\begin{tabular}{|l|l|l|}
\hline Degree of contribution in discussions & 27 & $81.8 \%$ \\
\hline Clarity of presented information & 29 & $87.9 \%$ \\
\hline Helpfulness to other group members & 25 & $75.8 \%$ \\
\hline Weaknesses as well as strengths & 25 & $75.8 \%$ \\
\hline
\end{tabular}

Table 2: Areas of peer-assessment at PBL sessions ( $\mathrm{n}=33$ )

Table 2 shows that the great majority stresses on all areas of peerassessment, especially the overall performance of their peers in $\mathrm{PBL}$ sessions.

\begin{tabular}{|l|l|l|}
\hline Characteristics & Number (N) & Percentage (\%) \\
\hline Regularity & 27 & $50.9 \%$ \\
\hline Allocation of enough time & 20 & $37.7 \%$ \\
\hline Moderation by the tutor & 27 & $50.9 \%$ \\
\hline Dependence on predetermined criteria & 22 & $41.5 \%$ \\
\hline
\end{tabular}

Table 3: Characteristics of the process of self- and peer-assessment done $(\mathrm{n}=53)$

* The total number $(\mathrm{n}=53)$ is the number of students who are doing self-assessment, peer-assessment, or both at the end of PBL sessions.

Table 3 shows that there is a problem in all the characteristics of the process of self- and peer-assessment, as only half of the students in the study reported that self- and peer-assessment is "done on regular basis" and is "moderated by the PBL tutor". Less than half of the students reported that the process is "allocated enough time" and "depends on a predetermined criteria". Such criteria are mainly set in the session by the tutor and not pre-set by the school.

\begin{tabular}{|l|l|l|l|}
\hline & $\begin{array}{l}\text { Do self- } \\
\text { assessment }\end{array}$ & $\begin{array}{l}\text { Don't do } \\
\text { self- } \\
\text { assessment }\end{array}$ & $\begin{array}{l}\text { p-value } \\
\text { (Fisher's } \\
\text { Exact Test) }\end{array}$ \\
\hline $\begin{array}{l}\text { Prior exposure to training on } \\
\text { self-assessment }(\mathrm{n}=22)\end{array}$ & $22(100 \%)$ & $0(0 \%)$ & $0.006^{*}$ \\
\hline $\begin{array}{l}\text { No prior exposure to training } \\
\text { on self-assessment (n=38) }\end{array}$ & $28(73.7 \%)$ & $10(26.3 \%)$ & \\
\hline
\end{tabular}

Table 4: Crosstab between prior exposure to training on selfassessment and doing self-assessment at PBL sessions

\section{* Statistically significant}

Table 4 shows that all the students who were previously exposed to formal or informal training on self-assessment really do selfassessment at PBL sessions. This is not the case with students who were not previously exposed to training, where a considerable percentage of them don't do self-assessment. The difference between the two groups is statistically significant.

\begin{tabular}{|l|l|l|l|}
\hline & $\begin{array}{l}\text { Do peer- } \\
\text { assessment }\end{array}$ & $\begin{array}{l}\text { Don't do } \\
\text { peer- } \\
\text { assessment }\end{array}$ & $\begin{array}{l}\text { p-value } \\
\text { (Pearson's Chi2 } \\
\text { Test) }\end{array}$ \\
\hline $\begin{array}{l}\text { Prior exposure to training on } \\
\text { peer-assessment }(n=22)\end{array}$ & $14(63.6 \%)$ & $8(36.7 \%)$ & 0.306 \\
\hline
\end{tabular}


Citation: Atwa HS, Al Rabia MW (2014) Self and Peer Assessment at Problem-Based Learning (PBL) Sessions at the Faculty of Medicine, King Abdulaziz University (FOM-KAU), KSA: Students Perception. Intel Prop Rights 2: 118. doi:10.4172/2375-4516.1000118

Page 4 of 6

No prior exposure to training

on peer-assessment $(n=38)$

$19(50 \%)$

$19(50 \%)$

Table 5: Crosstab between prior exposure to training on peerassessment and doing peer-assessment at PBL sessions
Table 5 shows that prior exposure to training on peer-assessment did not affect much the students' interest to do or not to do peerassessment.

\begin{tabular}{|l|l|l|l|l|}
\hline Self-assessment & Agree & Neutral & Disagree & $\begin{array}{l}\text {-value } \\
\text { (t-test) }\end{array}$ \\
\hline induces a strong sense of ownership and personal responsibility & 50 & 8 & 2 & $0.000^{*}$ \\
\hline encourages a deep learning approach & 54 & 5 & 1 & $0.000^{*}$ \\
\hline encourages self-learning & 56 & 4 & 0 & $0.000^{*}$ \\
\hline uncovers performance/knowledge weaknesses & 51 & 9 & 0 & $0.000^{*}$ \\
\hline encourages self-confidence & 49 & 10 & 1 & $0.000^{*}$ \\
\hline encourages honesty & 46 & 13 & 1 & $0.000^{*}$ \\
\hline encourages reflection skills & 40 & 19 & 1 & $0.000^{*}$ \\
\hline encourages better participation of students to avoid bad assessment & 54 & 5 & 1 & $0.000^{*}$ \\
\hline encourages development of judgment skills & 41 & 17 & 2 & $0.000^{*}$ \\
\hline
\end{tabular}

Table 6: Perception of the students regarding the importance and merits of self-assessment $(n=60)$

${ }^{*}$ Highly Statistically Significant

Table 6 shows the high student perception of the importance and merits of self-assessment. The great majority of the students agree on all the given statements describing the benefits gained through selfassessment. The differences between the groups of perceived responses are highly statistically significant.

\begin{tabular}{|c|c|c|c|c|}
\hline Self-assessment & Agree & Neutral & Disagree & $\begin{array}{l}\text { p-value } \\
\text { (t-test) }\end{array}$ \\
\hline induces a strong sense of ownership and personal responsibility & 35 & 19 & 6 & $0.000^{*}$ \\
\hline encourages a deep learning approach & 41 & 16 & 3 & $0.000^{*}$ \\
\hline encourages interpersonal communication between students & 42 & 17 & 1 & $0.000^{*}$ \\
\hline uncovers performance/knowledge weaknesses & 45 & 13 & 2 & $0.000^{*}$ \\
\hline provides a reliable assessment that comes from several sources (peers) & 41 & 19 & 0 & $0.000^{*}$ \\
\hline encourages self-confidence & 39 & 18 & 3 & $0.000^{*}$ \\
\hline encourages honesty & 38 & 20 & 2 & $0.000^{*}$ \\
\hline encourages development of judgment skills & 45 & 14 & 1 & $0.000^{*}$ \\
\hline provides a valuable source of feedback & 40 & 17 & 3 & $0.000^{*}$ \\
\hline encourages better participation of students to avoid bad assessment & 45 & 15 & 0 & $0.000^{*}$ \\
\hline encourages reflection skills & 43 & 15 & 2 & $0.000^{*}$ \\
\hline
\end{tabular}

Table 7: Perception of the students regarding the importance and merits of peer-assessment $(n=60)$

\section{${ }^{*}$ Highly Statistically Significant}

Table 7 shows the high student perception of the importance and merits of peer-assessment. The majority of the students agree on all the given statements describing the benefits gained through peerassessment. The differences between the groups of perceived responses are highly statistically significant.

\section{Results}

Training on different skills practiced at PBL sessions is important. However, only one third of our sample reported receiving training on self- and peer- assessment, which means that training, is not done systematically or for all students. Moreover, training that those 
students received may be extra-curricular and self-dependent either by asking PBL tutors "how to do" or through exposure to other training programs with the issue of self- and peer-assessment included.

Regardless of receiving training or not, most of the students do selfassessment. However, all students who received prior training reported that they do self-assessment. This indicates that training fosters the awareness of the students with the importance of selfassessment and makes them keen to do it.

When they do self-assessment, most of the students stress on all areas of self-assessment. This is most prominent in "overall performance". The great majority of students find it easy just to comment on their overall performance without going into deeper details about specific components of self-assessment to avoid embarrassment in front of tutors and other colleagues. As the "degree of contribution in discussions" and "weaknesses and strengths" are notable and are considered by other students, most of the students (92\%) commented on them.

Avoiding embarrassment and conflicts with colleagues explains why only half of the students do peer-assessment. Moreover, when they do peer-assessment they stress on "overall performance". Stressing on overall performance in peer-assessment is done by the great majority of students, again because they prefer just to avoid embarrassing colleagues so they don't prefer to go in deeper details about peers' performance in other areas of assessment.

Four characteristics of the process of self- and peer-assessment were checked for in this study. Those characteristics were regularity, time allocated, moderation by tutors, and dependence on predetermined criteria. Only half of the students said that the process of self and peerassessment is done on regular basis and is moderated by the PBL class tutor. Less than half of the students said that the process is allocated enough time and depends on predetermined criteria. This indicates that there is a problem in planning, implementation, and monitoring of the process of PBL and also lack of awareness or interest of the tutors about the importance of self- and peer-assessment.

Self-assessment is highly positively perceived by the students. This is indicated by the greater number of students who "agreed", compared to the number of those who "disagreed", on all the statements that describe the merits and importance of self-assessment (there is high statistical significance). This indicates that he students are aware of the need for applying self-assessment at PBL sessions. Peer-assessment is also positively perceived by the students, although the number of students who are "neutral" regarding most of the statements is not low.

Positive perception of self- and peer-assessment is probably due to the suggestion that medical students know that they will work in health teams after graduation, in which assessing self, peer, and subordinates is important to the functioning of teams.

\section{Conclusion}

Based on the importance and merits of self- and peer-assessment, they are positively perceived by nearly all the students in our sample, either those who do or those who don't do them. This provides a good ground for implementing and monitoring a sound strategy for selfand peer-assessment, based on pre-determined criteria, at FOM-KAU.

More attention should be paid by the FOM-KAU administration, and those responsible for the PBL program, to self- and peerassessment as important skills that are not only related to PBL but also reflected on all the activities of medical students and health professions graduates.

Awareness of the tutors about the importance of self- and peerassessment should be raised so they become keen to apply them with their PBL groups.

\section{Acknowledgements}

We would like to acknowledge the support of the administration of the Faculty of Medicine, King Abdulaziz University for facilitating our work. Special thanks to the 3rd year medical students who participated in the research.

\section{References}

1. Al-Shawwa L (2001) Preparing Faculty Members as PBL Tutors in King Abdul Aziz University, Jeddah, Saudi Arabia. Med J Cairo Univ 79: 185-191.

2. Barrows H, Tamblyn R (1980) Problem-Based Learning: An Approach to Medical Education. Springer, New York.

3. Boud D, Feletti G (1998) Changing problem-based learning: Introduction to the second edition. In: Boud D and Feletti G (Eds.): The Challenge of Problem-Based Learning. Kogan Page, London.

4. Neufeld V, Barrows H (1974) "The McMaster philosophy": An approach to medical education. Med Educ 49: 1040-1050.

5. Schmidt H (1993) Foundations of Problem-Based Learning: Some Explanatory Notes. Med Educ 27: 422-432.

6. Barrows H (2000) Problem-based learning applied to medical education. Revised edition. Southern Illinois University School of Medicine, Springfield, Illinois, USA.

7. Woods D (1985) Problem-based learning and problem-solving. In: Boud D. (Ed.): Problem-Based Learning for the Professions. HERDSA, Sydney.

8. Willem S, de Grave J, Moust H (1985) et al. Tutorials in Problem-Based Learning. Volume II: A new direction in teaching the health professions: 13-28.

9. Langendyk V (2006) Not knowing that they do not know: self-assessment accuracy of third-year medical students. Med Educ 40: 173-179.

10. Duffy FD, Holmboe ES (2006) Self-assessment in lifelong learning and improving performance in practice: physician know thyself. JAMA 296: 1137-1139.

11. Tyssen R, Vaglum P, Gronvold N (2001) Factors in medical school that predict postgraduate mental health problems in need of treatment. A nationwide and longitudinal study. Med Educ 35: 110-120.

12. Boud D, Cohen R, Sampson J (2001) Peer learning and assessment. In: Boud R and Sampson J (Eds.): Peer Learning in Higher Education (London, Kogan Page) 67-81.

13. Woods D (1994) Problem-based Learning: How to Gain the Most from PBL, Waterdown, ON: Donald R. Woods.

14. Boud D (1995) Enhancing Learning through Self-Assessment. London. Routledge Falmer.

15. Brown S, Glasner A (2003) Assessment Matters in Higher Education: Choosing and Using Diverse Approaches. Buckingham. The Society for Research into Higher Education \& Open University Press.

16. Brown S, Rust C, Gibbs G (1994) Involving students in the assessment process. In: Strategies for Diversifying Assessments in Higher Education. The Oxford Centre for Staff Development, Oxford. Oxonion Rewley Press.

17. Zariski A (1996) Student peer assessment in tertiary education: Promise, perils and practice. In Abbott J and Willcoxson L (Eds), Teaching and Learning Within and Across Disciplines: 189-200.

18. Race P (1998) Practical Pointers in Peer Assessment, 113-122. In: Peer Assessment in Practice, Brown S (Ed.) (SEDA paper 102) Birmingham: SEDA. 
Citation: Atwa HS, Al Rabia MW (2014) Self and Peer Assessment at Problem-Based Learning (PBL) Sessions at the Faculty of Medicine, King Abdulaziz University (FOM-KAU), KSA: Students Perception. Intel Prop Rights 2: 118. doi:10.4172/2375-4516.1000118

Page 6 of 6

19. Machado J, Machado V, Grec W (2008) Self- and peer assessment may not be an accurate measure of PBL tutorial process. BMC Medical Education 8: 55.

20. University of Reading. Peer and self-assessment.
21. Falchikov N (2003) Involving students in assessment. Psychology Learning and Teaching. 3: 102-108.

22. Sluijsmans D, Moerkerke G, van MerrKnboer J (2001) Peer assessment in problem based learning. Studies in Educational Evaluation 27: 153-173. 